"Przegląd Prawa Konstytucyjnego" Nr $3(15) / 2013$

\title{
Sprawozdanie
}

\section{Ogólnopolska interdyscyplinarna konferencja naukowa: Wyzwania wspótczesnego prawa wyborczego, Toruń, 15 marca 2013 r.}

W dniu 15 marca 2013 r. na Wydziale Prawa i Administracji Uniwersytetu Mikołaja Kopernika w Toruniu odbyła się Ogólnopolska Interdyscyplinarna Konferencja Naukowa pt. „Wyzwania współczesnego prawa wyborczego”. Było to przedsięwzięcie unikatowe w skali kraju, gdyż jej organizatorem było Studenckie Koło Naukowe Prawa Wyborczego „Elektor” UMK. Inicjatywa, jaką podjęli studenci, była godna uwagi, albowiem czas, jaki minął po ustanowieniu kodeksu wyborczego, był dobrym momentem do tego, by dokonać głębokiej refleksji na temat potrzeb wprowadzenia zmian w prawie wyborczym.

Uczestnikami konferencji byli znakomici przedstawiciele praktyki i doktryny polskiego prawa wyborczego - przewodniczący Państwowej Komisji Wyborczej, sędzia Stefan J. Jaworski, szef Krajowego Biura Wyborczego, Sekretarz PKW, minister Kazimierz W. Czaplicki, dyrektor Zespołu Prawa Konstytucyjnego i Międzynarodowego w Biurze Rzecznika Praw Obywatelskich, Mirosław Wróblewski, election adviser w OSCE/ODIHR, Alexander Shlyk, kierownik Centrum Studiów Wyborczych UMK, prof. dr hab. Andrzej Sokala oraz przedstawiciel Instytutu Spraw Publicznych, dr Jarosław Zbieranek.

Zdaniem przewodniczącego PKW wyzwaniem współczesnego prawa wyborczego jest odpowiedź na pytanie o to, co zrobić, aby zmobilizować inne ośrodki akademickie do organizowania akcji edukacyjnych z zakresu wiedzy obywatelskiej (prawa wyborczego). Zdaniem przewodniczącego wyzwaniem dla ustawodawcy byłaby próba odstąpienia od zamkniętego katalogu źródeł prawa. W obecnym stanie prawnym kwestie związane z rejestrem 
wyborców reguluje rozporządzenie ministra spraw wewnętrznych, zaś wzór sprawozdania finansowego minister finansów. Tymczasem konstytucjonalizacja PKW umożliwiłaby stanowienie norm prawnych o charakterze prawa powszechnie obowiązującego.

Minister Czaplicki zwrócił uwagę na zagadnienie równości szans: komitetów, partii politycznych, wyborów, uczestników wyborów. Szeroki rozwój środków komunikowania się (Internet, media społecznościowe) stawia olbrzymie wyzwania dla polskiego prawa wyborczego. Minister przypomniał, iż w 2014 r. odbędą się wybory posłów do Parlamentu Europejskiego i organów samorządu terytorialnego, zaś w 2015 r. - wybory do Sejmu i Senatu oraz na urząd prezydenta RP. Zdaniem K. Czaplickiego w zasadzie równości szans mieści się zasada powszechności i zasada równego dostępu do środków informacji.

W opinii Mirosława Wróblewskiego istotnym wyzwaniem jest korzystanie z czynnego prawa wyborczego przez osoby, które z jakichkolwiek powodów mają tę możliwość ograniczoną. Istotną rolę odgrywa problematyka dostosowywania lokali wyborczych do potrzeb osób niepełnosprawnych. Ustawodawca dokonał „rewolucji”, gdyż określił horyzont czasowy na dostosowanie budynków użyteczności publicznej do potrzeb osób niepełnosprawnych. Zdaniem mówcy konieczne jest dostarczenie przez parlament środków do prowadzenia akcji edukacyjnych i informacyjnych, które powinny odbywać się w sposób systematyczny. Dyskutant wskazywał na potrzebę wprowadzania racjonalnych udogodnień dla osób niepełnosprawnych.

Alexander Shlyk, reprezentujący Wydział Wyborów oddziału OBWE w Warszawie, wyjaśnił, że zainteresowanie organizacji skupia się na zbadaniu, czy prawo wyborcze jest zgodne z zobowiązaniami OBWE, a także czy wybory są przeprowadzane zgodnie z prawem wyborczym. Zdaniem mówcy wybory powinny spełniać 8 warunków, takich jak: wybory periodyczne, wolne, równe, uczciwe, tajne, powszechne, nadto przejrzyste (w ujęciu praktycznym) i prawdziwe (respektujące wolność wypowiedzi, zgromadzeń). Zdaniem eksperta trzeba mieć na uwadze praktykę stosowania przepisów prawa wyborczego.

W opinii Jarosława Zbieranka wyzwaniem z zakresu prawa wyborczego jest stworzenie projektu społecznego tłumaczącego praktyczne funkcjonowanie alternatywnych metod głosowania. A zatem konieczne jest opracowa- 
nie procedur informacyjnych, które propagowałyby wiedzę o podmiotowych prawach wyborczych i możliwościach ich realizacji. Ponadto mówca zwrócił uwagę na zmianę wiążącą się z nowelizacją ustawy o ewidencji ludności. Polska zaczyna podążać w kierunku krajów anglosaskich, w których wyborcy sami muszą wpisać się do rejestru wyborców.

Zdaniem prof. dr hab. Andrzeja Sokali budowa systemu wyborczego w Polsce po 1989 r. była udanym przedsięwzięciem. Nie oznacza to jednak, że nie brakuje rzeczy, których nie można i trzeba poprawić. Praktyka wyborcza weryfikuje przepisy prawne stanowione przez ustawodawcę. Niezmiernie istotne jest informowanie, edukowanie. Edukacja powinna być kierowana do wszystkich podmiotów uczestniczących w procesie wyborczym. Propagowanie wiedzy dotyczącej sposobów głosowania przez wyborców niepełnosprawnych i starszych powinno być zadaniem władz samorządowych. Prof. Sokala zwrócił uwagę uczestników konferencji, iż niedawno odbyła się w Polsce ankieta konstytucyjna. W opinii profesora należy wzmocnić instytucjonalnie Państwową Komisję Wyborczą poprzez jej konstytucjonalizację, która stworzyłaby prawne umocowanie do wydawania aktów prawa powszechnie obowiązującego. Prof. Sokala podkreślił znaczenie wartości, jaką jest stabilizacja prawa wyborczego. Nie należy podtrzymywać dotychczasowej praktyki dokonywania zmian w prawie wyborczym na krótko przed kolejną elekcją. Potrzebne jest zgłaszanie konstruktywnych propozycji zmian legislacyjnych. Prof. Sokala zwrócił uwagę na konieczność informowania o alternatywnych metodach głosowania, gdyż wiadomość o nich dociera bardzo wolno (np. mała liczba osób korzystających z nakładek w alfabecie Braille’a na kartę do głosowania). W opinii prof. Sokali nie należy absolutyzować zasad prawa wyborczego. Co prawda są to pewne kardynalne reguły, dyrektywy, ale wszystkie one ulegają ograniczeniu ze względu na ważne dobra. Natomiast ich ograniczenia nie mogą wychodzić poza granice dopuszczalnych odstępstw. Jako przykład profesor wskazał progi wyborcze - to odstępstwo od zasady równości na rzecz wartości, jaką jest stabilizacja rządów.

Dyskusja, jaka miała miejsce podczas obrad panelu eksperckiego, zasygnalizowała mnogość problemów, występujących na różnych etapach procedury wyborczej. Wybory to nie tylko sama procedura głosowania, ale wiele innych zagadnień, które znalazły odzwierciedlenie w tytułach poszczególnych paneli konferencji. 
Panel pierwszy pt. „Głosowanie - stan obecny i postulaty” zawierał wystąpienia poświęcone konstrukcji pełnomocnictwa do głosowania, sytuacji pacjenta jako wyborcy, głosowania korespondencyjnego Polaków przebywających zagranica, none of the above, a także zalet i wad e-votingu jako alternatywnej metody głosowania.

Kolejny panel - „Bezpieczeństwo wyborów - sankcje i gwarancje” - poświecony był zagadnieniu penalizacji wybranych czynów zabronionych w polskim kodeksie wyborczym, analizie wyników badań statystycznych czynów zabronionych przeciwko wyborom stypizowanych w kodeksie karnym, problematyki korupcji wyborczej, analizie instytucji mężów zaufania $\mathrm{w}$ polskim prawie wyborczym oraz międzynarodowej obserwacji wyborów prezydenckich na Ukrainie w $2010 \mathrm{r}$.

Kolejny panel pt. „Prawo wyborcze w wybranych państwach świata” grupował referaty dotyczące partycypacji politycznej kobiet w systemie wyborczym Kenii, Tanzanii oraz Ugandy, systemu wyborczego Republiki Malty, Stanów Zjednoczonych Ameryki Północnej, reguł finansowania kampanii wyborczej na Ukrainie w 2012 r. czy standardów wyborczych w demokracjach europejskich a Węgier po reformie konstytucyjnej w $2011 \mathrm{r}$.

Następny panel był poświęcony kampanii wyborczej w Polsce. Podczas obrad dyskutowano na temat wykorzystania wizerunku polityka w trakcie kampanii wyborczej i po niej, ghostwritingu w kampanii wyborczej na gruncie kodeksu wyborczego oraz ustawy o prawie autorskim i prawach pokrewnych, roli kampanii wyborczych w podwyższaniu jakości polskiego życia publicznego, problemu granic kampanii informacyjnych w kontekście agitacji wyborczej czy ochrony dóbr osobistych polityków w szczególnym trybie wyborczym.

Dalszy panel dotyczył zagadnienia równości w prawie wyborczym. Dyskutanci podczas obrad omawiali zagadnienia zwiększenia partycypacji kobiet w polskiej polityce na przykładzie wyborów parlamentarnych w $2011 \mathrm{r}$., skutki wprowadzenia parytetu wyborczego, wpływ gerrymanderingu na demokrację przedstawicielską, analizy politologicznej zasady konkurencyjności wyborów czy udziału mediów w kampanii wyborczej.

Podczas obrad kolejnego panelu pt. „Prawo wyborcze wobec potrzeb współczesnych społeczeństw" uczestnicy konferencji wysłuchali wystąpień poświęconych ustanawianiu cenzusów wyborczych w XXI w., likwidacji 
obowiązku meldunkowego i jego wpływu na rejestr wyborców, analizy socjologiczno-prawnej potrzeby uregulowania sondażu przedwyborczego, zagadnieniu ciszy wyborczej czy nowych typów demokracji.

Podczas dwóch końcowych paneli dyskutanci omawiali problematykę jednomandatowych okręgów wyborczych w wyborach do Sejmu, Senatu, w wyborach samorządowych, a także projektu zmian w kodeksie wyborczym dla Obywatelskiej Inicjatywy Ustawodawczej.

Ostatni panel pt. „Wyborczy kalejdoskop” zawierał ciekawe wystąpienia dotyczące zasad coachingu a współczesnego prawa wyborczego, prawa wyborczego w polskich konstytucjach, realizacji zasady demokratycznego przeprowadzania wyborów w polskich związkach sportowych na przykładzie Polskiego Związku Piłki Nożnej, motywowania partycypacji wyborczej w Polsce czy kulturowej a kulturalnej transgresji podmiotu względem wyborczego prawa stanowionego.

Tematyka poruszona podczas obrad odzwierciedlała interdyscyplinarny charakter konferencji, a omawiane zagadnienia nakreśliły nowe pola badawcze. Konferencja była udanym przedsięwzięciem organizacyjnym, co wypada podkreślić - pierwszym w wymiarze ogólnopolskim, zorganizowanym przez Studenckie Koło Naukowe i w całości poświęconym wyzwaniom współczesnego prawa wyborczego.

Radosław Zych

Centrum Studiów Wyborczych Uniwersytetu Mikołaja Kopernika w Toruniu 